\title{
Habitat selection by anchovies (Clupeiformes: Engraulidae) in a tropical bay at Southeastern Brazil
}

\author{
Francisco G. Araújo, Marcio A. Silva, Joaquim N. S. Santos and Ruan M. Vasconcellos
}

Distribution of anchovies (Clupeiformes, Engraulidae) was described in the Sepetiba Bay, a coastal area of Southeastern Brazil, to assess eventual mechanisms of habitat selection. Two fish sampling programmes were accomplished; one using beach seine $(1998 / 2000)$ to catch juveniles in sandy beaches, and the other, using seines (1999/2000) to catch adults in deeper bay areas. Six species representing 4 genera were recorded: Anchoa tricolor, Anchoa januaria, Anchoa lyolepis, Cetengraulis edentulus, Engraulis anchoita and Lycengraulis grossidens. Anchoa tricolor and A. januaria were the most abundant species, with the former peaking in the outer bay, while the latter peaking in the inner bay. Adults A. tricolor are target of heavy commercial fisheries in the bay during Spring-Summer, while E. anchoita, an abundant species in the continental shelf, was occasionally caught in large numbers during the Autumn. The habitat selection, by using two different bay areas, was developed by the two most abundant species, a probable mechanism to enable their coexistence.

A distribuição de manjubas (Clupeiformes, Engraulidae) foi descrita na Baía de Sepetiba, uma área costeira do Sudeste do Brasil, para determinar eventuais mecanismos de seleção de habitat. Dois programas de amostragem foram realizados; um usando arrasto de praia (1998/2000) para captura de juvenis, e outro, usando arrasto de fundo (1999/2000) para captura de adultos. Seis espécies representadas por quatro gêneros foram capturadas: Anchoa tricolor, Anchoa januaria, Anchoa lyolepis, Cetengraulis edentulus, Engraulis anchoita e Lycengraulis grossidens. Anchoa tricolor e A. januaria foram as espécies mais abundantes, com a primeira ocorrendo principalmente na zona externa da baía, enquanto a segunda com maior abundância na zona interna. Adultos A. tricolor são alvo de intensas pescarias comercial na baía durante a Primavera-Verão, enquanto $E$. anchoita, uma abundante espécie na plataforma continental, foi ocasionalmente capturada em grande numero durante o Outono. A seleção de hábitat, através do uso de diferentes áreas da baía, foi desenvolvida pelas duas espécies mais abundantes, um provável mecanismo para permitir a coexistência.

Key words: Fish distribution, Sandy beach, Anchovy, Sepetiba bay.

\section{Introduction}

Fishes of the Engraulidae family, known as anchovies, are widely distributed in tropical and sub-tropical waters (Mcgowan \& Berry, 1983). In Sepetiba Bay, a 450 km² embayment of Brazilian Southeastern coast, they rank among the most abundant species either as juveniles recruits in the sandy beaches, and as adults, occupying different areas in the inner and outer bay zones. Most anchovies spawn in open coastal areas in the inner continental shelf. Recruitment occurs in protected, shallow areas that offer food and shelter against predators (Coto et al., 1988). Adults have been demonstrated to move on seasonal and diel timescales between open coastal areas and bays (Macgregor \& Houde, 1996), where they form large aggregations that are targeted by important fisheries. Engraulidae fishes are believed to be a major trophic link in bay food chains through their role in converting planktonic biomass into forage for piscivorous fishes (Hildebrand, 1963).

Sepetiba Bay (Fig. 1) is located in the State of Rio de Janeiro, Southeastern Brazil. Several marine fishes enter and leave the bay for nursery, reproductive and feeding purposes (Araújo et al., 2002). There is a trend of decreasing water quality in the bay. Recent enhancement of the Sepetiba Bay Port included dredging of the access channel to $20 \mathrm{~m}$ depth, which will enable it to receive ships up to 150,000 ton of capacity.

Three species of the Engraulidae family: Anchoa januaria (Steindachner, 1879), Anchoa tricolor (Spix \& Agassiz, 1829) and Cetengraulis edentulus (Cuvier, 1829) rank among the most abundant fishes in the Sepetiba Bay (Pessanha et al., 2003) although their coexistence mechanisms and population biology are poorly known. High diversity and abundance of Engraulidae in the Sepetiba Bay suggest that some mechanisms of the resources and habitat partition occur in order to avoid competition (Silva \& Araújo, 2000); they justified coexistence

Universidade Federal Rural do Rio de Janeiro; Laboratório de Ecologia de Peixes; Km 47, Antiga Rodovia Rio-São Paulo, 23851-970 Seropédica, Rio de Janeiro, Brazil. gerson@ufrrj.br 
as result of use of different resources supplied by different areas in the bay. Species that share the same area use different strategies to explore the available food resources. Sergipense $e t$ al. (1999) found that A. januaria and C. edentulus, common in the inner Sepetiba Bay area, have a different feeding strategy, with the first species feeding predominantly on zooplankton and the latter feeding on phytoplankton. Heavy rainfall seasons seem to increase plankton availability, due to great amount of nutrients brought by rivers, favoring the development of planktofagous fish (Macgregor \& Houde, 1996).

Environmental variables could also influence the period that these fishes migrate from the bay to open areas in the inner continental shelf and vice-versa. Anchoa marinii Hildebrand, 1943 movement from coastal areas to the Patos Lagoon estuary was associated to intrusion of high salinity deep waters, while Lycengraulis grossidens Agassiz, 1829 was associated to areas of low salinity (Weiss \& Krug, 1977). In the Sepetiba Bay, Silva et al. (2004) found that young-of-the-year of A. januaria occur in shallow and transparent waters, while Sergipense \& Sazima (1995) found this species mostly in sites with more influence of continental drainages. Cetengraulis edentulus occurs mainly near to muddy substrate (Gay et al., 2000).

The present work aims to assess mechanisms of habitat selection by species of Engraulidae in the Sepetiba Bay, by investigating their spatial and seasonal distribution, and to verify the influences of the environmental variables. Specifically, the use of select habitats (inner bay and outer bay) was evaluated by indices of anchovies abundance, as determined from seine and beach seine surveys. In an effort to better understand the mechanisms underlying habitat selection, anchovies abundances were correlated with several abiotic parameters measured at the sampling sites.

\section{Material and Methods}

\section{Study area}

Sepetiba Bay (Fig. 1) is a sedimentary embayment in the coast of Rio de Janeiro State (Lat. $22^{\circ} 54^{\prime}-23^{\circ} 04^{\prime}$ 'S; Long. $43^{\circ} 34^{\prime}-44^{\circ} 10^{\prime} \mathrm{W}$ ) in southeastern Brazil. It originated by an extensive process of sand deposition, which formed a barrier beach at its southern end. It has a wide communication with the Atlantic Ocean at its western end. The bay has a surface area of approximately $450 \mathrm{~km}^{2}$, a mean depth of $8.6 \mathrm{~m}$, a maximum depth of $30 \mathrm{~m}$, and is within a drainage area of $2700 \mathrm{~km} 2$. Waters are predominantly polyhaline (salinity average $=30$ ). The annual rainfall is between $1000 \mathrm{~mm}$ and $2100 \mathrm{~mm}$ (Barbieri \& Kronemberger, 1994) but this does not influence the bay salinity much due the existence of only small tributaries. Most of the substrate is silt and mud. The tidal range is approximately $1 \mathrm{~m}$. Predominant north-easterly and south-westerly winds activate thermal currents between the bay and the ocean.

Two bay zones were arbitrarily defined to maximize variation in habitat characteristics, defined according to depth, salinity, transparency, temperature and influences of human activities (Fig. 1). The outer zone has a sandy and gravel bot-

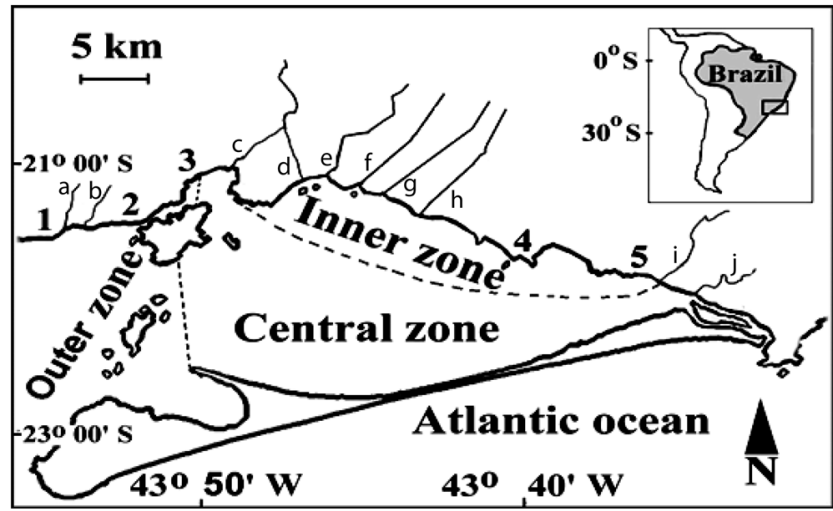

Fig. 1. Study area, Sepetiba Bay, Brazil, with indication of the beach seine sampling sites (1-5). a - rio Prata; $b$ - rio Corumbi; c - rio Cação; d - rio Mazomba; e - rio Guarda; f - canal São Francisco; g - canal Guandu; h - canal Itá; i - rio Piraquê; j - rio Piracão.

tom and was close to the sea limit (highest salinity, transparency, depth and lowest temperature); and the inner zone, with opposite oceanographic conditions, has a heavy mud bottom and was located within a protected area of the bay, near to anthropogenic influences from urban-industrial wastes.

Sampling. Two fish sampling programmes were accomplished, one using beach seine nets to caught early juveniles, and other using seines to catch adults in deeper bay areas. Beach seines were performed monthly, from September 1998 to August 2000, at five sites, during the day. A $10 \mathrm{~m}$ long, 2 $\mathrm{m}$ deep beach seine with $7 \mathrm{~mm}$ mesh was used. The net was pulled through the water parallel and close to the shore for a distance of $30 \mathrm{~m}$ at approximately, $1.5 \mathrm{~m}$ depth, and then onto the shore. Three replicates seines were performed at each site. Monthly samples were carried out at sites 1, 2 and 3 (outer zone), and sites 4 and 5 (inner zone) (Fig. 1).

Seines in deep areas were carried out using a $15 \mathrm{~m}$ long boat provided with an acoustics echosounder Royal RV400 equipment to monitor fishing procedure. The net was $240 \mathrm{~m}$ long, $27 \mathrm{~m}$ deep and size mesh of $8 \mathrm{~mm}$ in the upper part and $10 \mathrm{~mm}$ in de lower part. Samplings were performed preferably near to central bay islands (Fig. 1). The net was released with the help of a small auxiliary boat used to anchor the net, while the fishing boat encircled the schooling, closing the net.

Water temperature and salinity were taken at every sampling occasion at approximately $0.5 \mathrm{~m}$ below surface water. A Sechi disc was used to measure water transparency which was calculated as percent of the depth (beach seines), which was determined with a weighted line marked in 10-cm intervals. Transparency was expressed in $\mathrm{cm}$ for the seine programme (adults). Fish were fixed in 10\% formalin, identified to species, counted, measured (total length in $\mathrm{mm}$ ) and weighed in grams. Sub-samples from very abundant catches were taken. After 2 days they were drained, soaked in fresh water for 2 hours and transferred to $70 \%$ ethanol for storage. Voucher specimens were deposited in the ichthyological collection of 
the Fish Ecology Laboratory, Universidade Federal Rural do Rio de Janeiro (LEP-UFRRJ).

Data analysis. The relative abundances (in number) were estimated from the sampling catch-per-unit-effort (CPUE, number / sample). A parametric three-way analysis of variance (ANOVA) and a Student-Newman-Keuls-SNK test ( $a=$ 0.05 ) were used to test for differences in numerical abundance of Engraulidae among sites, seasons and years for juveniles (beach seine). One-way ANOVA was used to compare number of individuals among season for adults (seine) and to compare number of individuals of both juveniles and adults among the ranges of environmental variables. Both biotic and environmental raw data were previously $\log _{10}(x+1)$ transformed to address ANOVA assumptions of normality and homocedasticity (Sokal \& Rohlf, 1981). Influences of environmental variables on fish occurrence were assessed by grouping fishes numbers in four intervals of temperature in degree Celsius $(1: \leq 24.1 ; 2: 24.1-28.0 ; 3: 28.1-32.0 ; 4: \geq$ $32.0)$, salinity $(1: \leq 20.1 ; 2: 20.1-25.0 ; 3: 25.1-30.0 ; 4: \geq 30.0)$, and transparency in $\%$ of depth $(1: \leq 25.1 ; 2: 25-50.0 ; 3: 50.1-$ $75.0 ; 4: \geq 75.0$ ) for beach seine samples (juveniles), and in three intervals of temperature in degree Celsius $(1:<23.1 ; 2$ : $23.1-26.0 ; 3:>26.0)$, salinity $(1:<25.1 ; 2) 25.1-30.0 ; 3:>$ $30.0)$ and transparency in $\mathrm{cm}(1:<180.0 ; 2: 180.1-290.0 ; 3$ : $>290.0$ ). Patterns between fish occurrence and environmental variables were assessed through a Canonical Correspondence Analysis-CCA (Teer Braak, 1986). This is one of the best methods for direct gradient analysis in community ecology (Rodriguez \& Lewis, 1997; Araújo et al., 2002) and is widely used to assess environmental influences on fish occurrence.

\section{Results}

\section{Composition and relative abundance}

Juveniles. A total of 20430 Engraulidae fishes were collected in beach seine, mainly young-of-the-year, being $67 \%$ in the $1998 / 99$ and $33 \%$ in 1999/00. Anchoa tricolor was the most abundant species, amounting to $77.45 \%$ of the total number of Engraulidae, followed by A. januaria $(20.02 \%)$, A. lyolepis $(2.49 \%)$ and $C$. edentulus $(0.03 \%)$. Only two individuals of $L$. grossidens were caught, therefore this species was not included in the analyses.

Spatial separation was shown for juveniles of different species (Fig. 2, Table 1). Anchoa tricolor, A. januaria, A. lyolepis and $C$. edentulus showed significant differences in numerical abundance $(\mathrm{p}<0.05)$ among sites (Table 1). Anchoa tricolor and $A$. lyolepis were more abundant in the outer zone, while $A$. januaria and $C$. edentulus, in the inner zone. Anchoa tricolor predominated at site 2, A. januaria at site 4, and A. lyolepis at site 1. Despite of low abundance, C. edentulus presented significant differences among sites, being more abundant at site 4 (Table 2). Factor interactions were mainly non-significant or with low significant $\mathrm{F}$-values, except for season versus year interactions for A. tricolor and A. lyolepis (Table 1). These significant interactions were due to the highest abundance of A. tricolor to be recorded in Spring in 1998/1999 (overall average $=212.0$ individuals per sample), and in Winter (49.9 individuals per sample) in 1999/2000, while A. lyolepis had the highest CPUE in Autumn (overall average $=8.2$ individuals per sample) in 1998/1999, and in Spring (overall average = 6.2 individuals per sample) in 1999/2000.

Seasonally, significant differences $(\mathrm{p}<0.05)$ were shown for A. tricolor, A lyolepsis and C. edentulus (Tables 1 and 2). Anchoa tricolor and A. lyolepsis were more abundant in Winter/Spring, and C. edentulus in Spring. Significant difference between the two-year period was found only for $A$. januaria that was more abundant in 1998/1999 than in 1999/2000.

Adults. Adults of A. tricolor and Engraulis anchoita caught by seines showed significant temporal variation in their densities in number of individuals, with A. tricolor being more

Table 1. F-Values and significance from three-way ANOVA for comparisons of number of juveniles individuals of each species from Engraulidae family among sites, season e years. ** higly significant $(\mathrm{p}<0.01)$; * significant $(\mathrm{p}<0.05)$; $\mathrm{ns}=$ non significant.

\begin{tabular}{lccccc}
\hline Main Effects & df & $\begin{array}{c}A . \\
\text { tricolor }\end{array}$ & $\begin{array}{c}A . \\
\text { januaria }\end{array}$ & $\begin{array}{c}A . \\
\text { lyolepis }\end{array}$ & $\begin{array}{c}C . \\
\text { edentulus }\end{array}$ \\
\hline Site & 4 & $8.71^{*}$ & $4.36^{*}$ & $14.40^{*}$ & $3.62 *$ \\
Season & 3 & $8.99^{*}$ & $0.29 \mathrm{~ns}$ & $5.86^{*}$ & $3.02 *$ \\
Year & 1 & $2.80 \mathrm{~ns}$ & $4.18^{*}$ & $0.38 \mathrm{~ns}$ & $2.59 \mathrm{~ns}$ \\
Site x Season & 12 & $2.84^{*}$ & $1.72 \mathrm{~ns}$ & $4.38^{*}$ & $1.82 *$ \\
Site x Year & 4 & $1.58 \mathrm{~ns}$ & $2.14 \mathrm{~ns}$ & $2.91 *$ & $1.49 \mathrm{~ns}$ \\
Season x Year & 3 & $7.68^{*}$ & $3.47 *$ & $8.31^{*}$ & $1.1 \mathrm{~ns}$ \\
Site x Season x Year & 12 & $1.02 \mathrm{~ns}$ & $2.39 *$ & $6.44 *$ & $0.62 \mathrm{~ns}$ \\
\hline
\end{tabular}

Table 2. Significant differences $(p<0.05)$ in number of individuals for both juveniles and adults of each species from Engraulidae family, among sites and seasons, according to Student-Newman-Keuls (SNK) test. Mean values (number of individuals / sample) in brackets.

\begin{tabular}{|c|c|c|c|c|}
\hline \multicolumn{5}{|c|}{ Juveniles } \\
\hline A. tricolor & Sites & $\begin{array}{c}2 \\
(134.1)\end{array}$ & $>$ & $\begin{array}{c}1,3,4,5 \\
(0.02-32.1)\end{array}$ \\
\hline & Sites & $\begin{array}{c}1,4,5 \\
(23.7-32.1)\end{array}$ & $>$ & $\begin{array}{c}3 \\
(0.02)\end{array}$ \\
\hline & Season & $\begin{array}{l}\text { Spring, Winter } \\
(41.6-115.9)\end{array}$ & $>$ & $\begin{array}{c}\text { Summer, Autumn } \\
(8.5-9.6)\end{array}$ \\
\hline \multirow[t]{2}{*}{ A. januaria } & Sites & $\begin{array}{c}4 \\
(12.7)\end{array}$ & $>$ & $\begin{array}{c}1,2,3,5 \\
(0.02-35.4)\end{array}$ \\
\hline & Year & $\begin{array}{l}1998 / 1999 \\
(22.1)\end{array}$ & $>$ & $\begin{array}{l}1999 / 2000 \\
((3.7)\end{array}$ \\
\hline \multirow[t]{2}{*}{ A. lyolepis } & Sites & $\begin{array}{c}1 \\
(7.1)\end{array}$ & $>$ & $\begin{array}{c}2,3,4,5 \\
(0.0-0.53)\end{array}$ \\
\hline & Season & $\begin{array}{l}\text { Spring, Winter } \\
(1.4-4.1)\end{array}$ & $>$ & $\begin{array}{l}\text { Summer, Autumn } \\
(0.0-0.12)\end{array}$ \\
\hline \multirow[t]{2}{*}{ C. edentulus } & Sites & $\begin{array}{c}4 \\
(0.02)\end{array}$ & $>$ & $\begin{array}{c}1,2,3,5 \\
(0.0-0.004)\end{array}$ \\
\hline & Season & $\begin{array}{l}\text { Spring } \\
(0.05) \\
\end{array}$ & $>$ & $\begin{array}{c}\text { Summer, Autumn, Winter } \\
(0.0-0.02)\end{array}$ \\
\hline \multicolumn{5}{|c|}{ Adults } \\
\hline A. tricolor & Season & $\begin{array}{c}\text { Spring, Summer } \\
(138.5-171.1)\end{array}$ & $>$ & $\begin{array}{c}\text { Autumn, Winter } \\
(15.2-33.5)\end{array}$ \\
\hline E. anchoita & Season & $\begin{array}{c}\text { Autumn } \\
(70.0)\end{array}$ & $>$ & $\begin{array}{c}\text { Spring, Summer, Winter } \\
(0.0-1.2)\end{array}$ \\
\hline
\end{tabular}




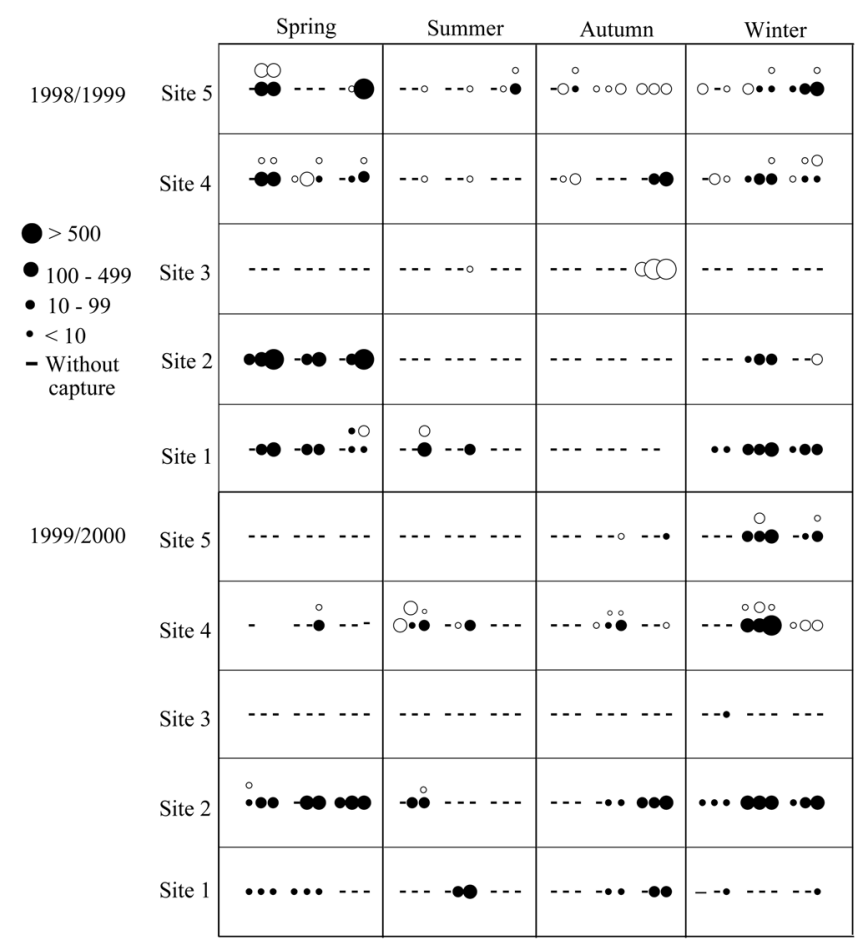

Fig. 2. Spatial and seasonal densities of juveniles $A$. januaria (o) and A. tricolor (•) in the Sepetiba Bay, 1998/2000. Each sample (mark in the graphic) represents the total number of fish.

abundant in Spring and Summer, while E. anchoita was more abundant in Autumn (Table 2). Adults Engraulidae amounted to $3145 \mathrm{~kg}, 86 \%$ comprised by A. tricolor, $9 \%$ E. anchoita, $4 \%$ A. januaria and $1 \%$ C. edentulus.

\section{Influence of environmental variables}

Juveniles. Anchoa tricolor and A. lyolepis showed significant differences in numerical abundance among the ranges of temperature, while A. tricolor and A. januaria showed differences among the ranges of salinity and transparency (Table 3 and 4). Anchoa tricolor peaked at temperature $<28^{\circ} \mathrm{C}$, while $A$. januaria showed no defined preference for a given range of temperature. Anchoa tricolor and A. lyolepis were more abundant in the highest salinity $(>25)$, while $A$. januaria and $C$. edentulous peaked in the lowest salinity $(<25)$ (Table 4). Anchoa tricolor and A. januaria were more abundant in intermediary range of transparency.

Canonical correspondence analysis showed for the first two axes eigenvalues of 0.212 and 0.027 , respectively, explaining $82.1 \%$ and $10.7 \%$ of the total variance (Table 5). The species-environmental correlation was 0.611 for the axis 1 and 0.269 for the axis 2. Correlation coefficients between the environmental variables and the two first ordination axes reflect the relative importance of each environmental variable in the species composition. Axis 1 corresponded to salinity and transparency gradient, with lower weight for the temperature, while axis 2 represents the salinity gradient. The main source of variation of the model is marked shift in the Engraulidae populations from the inner to the outer zone, along axis 1 , coinciding with spatial gradient of transparency and salinity. The ordination diagram of the first two axes separates on the left side samples from outer zone, characterized by higher transparency and salinity, in opposition to samples from inner zone on the right side, which are characterized by higher temperature and lower transparency and salinity (Fig. 3).

Adults. Significant differences $(\mathrm{p}<0.05)$ were detected in abundance (in numbers) among the ranges of temperature for A. tricolor and A. januaria, and among the ranges of salinity for A. januaria (Table 4). A. tricolor showed significant $(\mathrm{p}<0.01)$ higher abundance in temperature higher than $23.1^{\circ} \mathrm{C}$, while $A$. januaria peaked in the lowest salinity range $(<25)$.

Canonical correspondence analysis showed for the first and second axes, eigenvalues of 0.633 and 0.204 , respectively, explaining $74.8 \%$ and $24.0 \%$ of the total variation (Table 6). The species-environmental correlation was 0.869 for axis 1 and 0.732 for axis 2 . Axis 1 corresponded to salinity and transparency gradient, while axis 2 represents the seasonal temperature variation (Fig. 4). The main source of variation of the model is a marked shift in the Engraulidae populations from Winter to Spring/Summer, with Autumn presenting an intermediary condition.

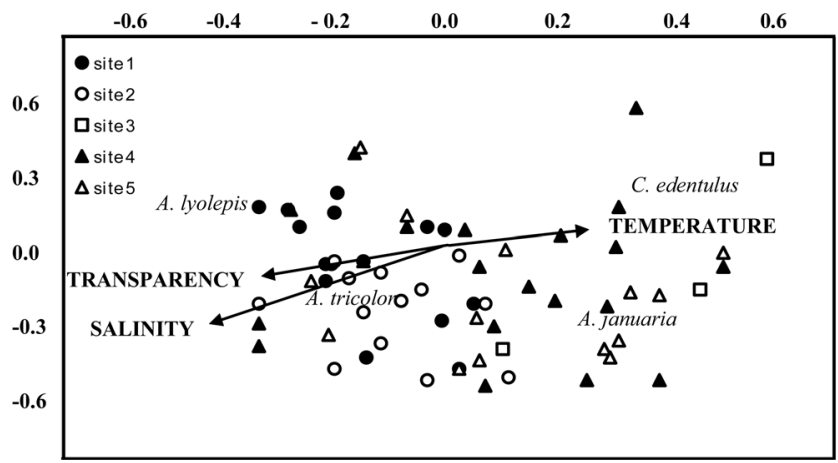

Fig. 3. Canonical correspondence analysis ordination diagram of juvenile Engraulidae abundance data, with environmental variables. Bay Zones: Sites 1, 2 and 3 (outer); 4 and 5 (inner).

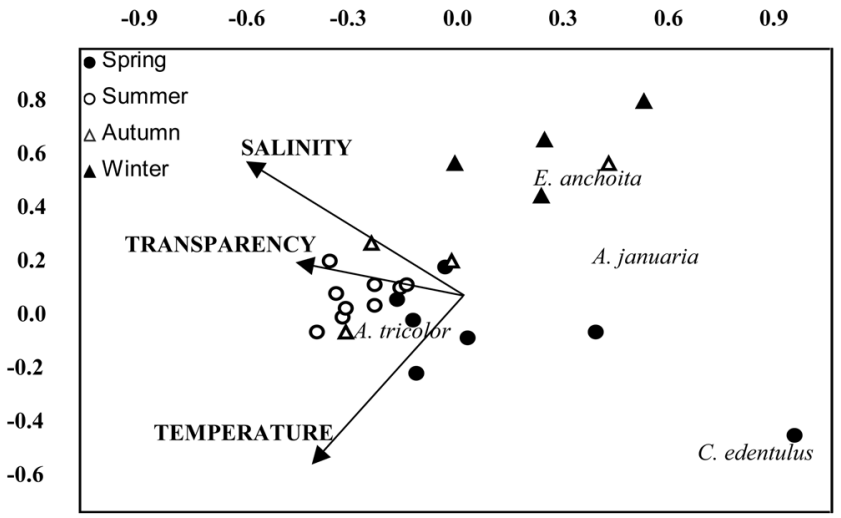

Fig. 4. Canonical correspondence analysis ordination diagram of adults Engraulidae abundance data, with environmental variables. Samples coded by seasons. 
Table 3. Means and standard deviation of number of individuals for ranges of enviromental variables.

\begin{tabular}{|c|c|c|c|c|c|}
\hline & A. tricolor & A. januaria & A. lyolepis & C. edentulus & E. anchoita \\
\hline \multicolumn{6}{|c|}{ Juveniles } \\
\hline \multicolumn{6}{|l|}{ Salinity } \\
\hline 1) $<20.1$ & $1.12 \pm 4.9$ & $65.69 \pm 268$ & 0 & $0.02 \pm 0.1$ & 0 \\
\hline 2) $20.1-25.0$ & $12.06 \pm 54.1$ & $14.10 \pm 54.1$ & $0.22 \pm 1.5$ & $0.06 \pm 0.3$ & 0 \\
\hline 3) $25.1-30.0$ & $58.62 \pm 392$ & $3.87 \pm 24.7$ & $2.38 \pm 18.9$ & $0.01 \pm 0.1$ & 0 \\
\hline 4) $>30.0$ & $46.98 \pm 130$ & $0.89 \pm 3.81$ & $0.15 \pm 1.3$ & 0 & 0 \\
\hline \multicolumn{6}{|l|}{ Temperature $\left({ }^{\circ} \mathrm{C}\right)$} \\
\hline 1) $<24.1$ & $38.6 \pm 109$ & $25 \pm 163$ & $4.4 \pm 25.8$ & 0 & 0 \\
\hline 2) $24.1-28.0$ & $89.9 \pm 535$ & $7 \pm 34.9$ & $0.009 \pm 0.09$ & $0.009 \pm 0.09$ & 0 \\
\hline 3) $28.1-32.0$ & $20.0 \pm 63.7$ & $6.5 \pm 36.7$ & $0.26 \pm 1.48$ & $0.06 \pm 0.28$ & 0 \\
\hline 4) $>32.0$ & $0.3 \pm 2.0$ & $0.06 \pm 0.2$ & 0 & 0 & 0 \\
\hline \multicolumn{6}{|c|}{ Transparency (\%depth) } \\
\hline 1) $<25.1$ & $11.07 \pm 34.4$ & $1.57 \pm 8.7$ & $0.34 \pm 2.38$ & $0.01 \pm 0.10$ & 0 \\
\hline 2) $25.1-50.0$ & $109 \pm 656$ & $46.4 \pm 210$ & $0.16 \pm 1.35$ & 0 & 0 \\
\hline 3) $50.1-75.0$ & $79.9 \pm 230$ & $4.47 \pm 19.8$ & 0 & $0.02 \pm 0.14$ & 0 \\
\hline 4) $>75.0$ & $28.1 \pm 108$ & $1.25 \pm 9.51$ & $0.83 \pm 7.47$ & 0 & 0 \\
\hline \multicolumn{6}{|c|}{ Adults } \\
\hline \multicolumn{6}{|l|}{ Salinity } \\
\hline 1) $<25.1$ & $25 \pm 35.3$ & $40 \pm 56.5$ & 0 & $10 \pm 14.14$ & 0 \\
\hline 2) $25.1-30.0$ & $141 \pm 147.7$ & 0 & 0 & 0 & $17.8 \pm 52.5$ \\
\hline 3) $>30.0$ & $66.5 \pm 64.1$ & $9.1 \pm 14.9$ & 0 & 0 & 0 \\
\hline \multicolumn{6}{|l|}{ Temperature $\left({ }^{0} \mathrm{C}\right)$} \\
\hline 1) $<23.1$ & $27 \pm 42.6$ & $11 \pm 15.9$ & 0 & 0 & $17 \pm 35.2$ \\
\hline 2) $23.1-26.0$ & $65 \pm 42.7$ & 0 & 0 & 0 & $40 \pm 89.4$ \\
\hline 3) $>26.0$ & $160.3 \pm 150$ & $5.7 \pm 21.3$ & 0 & $1.42 \pm 5.34$ & 0 \\
\hline \multicolumn{6}{|l|}{ Transparency $(\mathrm{cm})$} \\
\hline 1) $<180.0$ & $91.7 \pm 107.9$ & $12.5 \pm 28.1$ & 0 & $2.5 \pm 7.07$ & $10 \pm 28.2$ \\
\hline 2) $180.1-290.0$ & $90.7 \pm 68.5$ & $2.5 \pm 9.3$ & 0 & 0 & $14.6 \pm 53.3$ \\
\hline 3) $>290.0$ & $350 \pm 353$ & 0 & 0 & 0 & 0 \\
\hline
\end{tabular}

The diagram separates the Spring/Summer samples on the left side, that is characterized by higher salinity and transparency, in opposition to the Winter samples, on the right side, that is characterized by lower salinity and transparency. The Autumn samples showed a wide distribution in the diagram, reflecting an intermediary condition and a wide variation of these environmental variables, with a slight trend to be closer to Spring/Summer samples. Axis 2 can be interpreted as temperature gradient in opposition to the salinity, with the

Table 4. Significant differences $(\mathrm{p}<0.05)$ in number of individuals for each species from Engraulidae family, among ranges of environmental variables, according to StudentNewman-Keuls (SNK) test. Mean values in brackets. Environmental ranges according to Table 3 .

\begin{tabular}{|c|c|c|c|}
\hline \multicolumn{4}{|c|}{ Juveniles } \\
\hline Temperature & & & \\
\hline Anchoa tricolor & $1,2,3(20.0-89.9)$ & $>$ & $4(0.2)$ \\
\hline Anchoa lyolepis & $1(5.9)$ & $>$ & $2,4(0.0-0.09)$ \\
\hline Salinity & & & \\
\hline Anchoa tricolor & 3,4 (46.9-58.6) & $>$ & $1,2(1.1-12.0)$ \\
\hline Anchoа јапиагіа & $1(65.6)$ & $>$ & $2,3,4(0.8-14.1)$ \\
\hline Transparency & & & \\
\hline Anchoa tricolor & $3(79.9)$ & $>$ & $1,4(11.0-28.1)$ \\
\hline Anchoa januaria & $2(46.4)$ & $>$ & $1,4(1.2-1.5)$ \\
\hline \multicolumn{4}{|c|}{ Adults } \\
\hline \multicolumn{4}{|l|}{ Temperature } \\
\hline Anchoa tricolor & $2,3(65.0-160.3)$ & $>$ & $1(27.0)$ \\
\hline Anchoa jапиагіа & $1(11.0)$ & $>$ & $2,3(0.0-5.7)$ \\
\hline Salinity & & & \\
\hline Anchoa januaria & $1(40.0)$ & $>$ & $2,3(0.0-9.1)$ \\
\hline
\end{tabular}

Spring/Summer samples concentrated on the lower part of the diagram, characterized by higher temperature and lower salinity, while the winter samples were distributed on the upper part, characterized by lower temperature and higher salinity.

\section{Discussion}

The most abundant members of the Engraulidae family in the Sepetiba Bay showed spatial separation during their early life cycle at the sandy beaches. Anchoa tricolor dominated in the outer bay zone, while $A$. januaria peaked in the inner bay zone. This agrees with May \& MacArthur (1972)

Table 5. Summary of the CCA performed on the abundance of juveniles species of Engraulidae family. Significant environmental variables were selected by a stepwise procedure analogous to forward elimination in multiple regression analysis. Significant values $(p<0.05)$ in bold.

\begin{tabular}{|c|c|c|c|c|}
\hline AXES & 1 & 2 & 3 & 4 \\
\hline \multicolumn{5}{|c|}{ Correlation of Environmental Variables } \\
\hline Salinity & -0.4089 & -0.1255 & -0.0048 & 0.0000 \\
\hline Temperature & 0.2533 & 0.0221 & 0.0573 & 0.0000 \\
\hline Transparency & -0.3276 & -0.0545 & -0.0704 & 0.0000 \\
\hline \multicolumn{5}{|c|}{ Summary Statistics for Ordination Axes } \\
\hline Eigenvalues & 0.212 & 0.027 & 0.019 & 0.394 \\
\hline Species-environment correlations & 0.611 & 0.269 & 0.231 & 0.000 \\
\hline \multicolumn{5}{|c|}{ Cumulative Percentage of Variance } \\
\hline of species data & 16.3 & 18.4 & 19.9 & 50.2 \\
\hline of species-environment correlations & 82.1 & 92.8 & 100.0 & 0.0 \\
\hline Sum of al Unconstrained Eigenvalues & \multicolumn{4}{|c|}{1.298} \\
\hline Sum of all Canonical Eigenvalues & \multicolumn{4}{|c|}{0.258} \\
\hline
\end{tabular}


statement which predicted on theoretical grounds that species segregating along a single niche dimension in a fluctuating environment must maintain a certain minimum niche difference. The distributional boundaries of each species reflect its relationship with the environment, including physiological responses to physical characteristics and various interactions with other species, including predators, prey and pathogens (Ricklefs \& Schluter, 1993). The successful recruitment and high abundance of these fishes in the sandy beaches in Sepetiba Bay (Silva et al., 2004) would be directly linked to this strategy and it was confirmed in the present work.

These two most abundant species have different areas of recruitment in the Bay. Young-of-the-year of A. tricolor recruits mainly in the outer bay zone. This area is located in a protected part of the bay due to its proximity to the largest isle, which enable recruitment in relatively calm and transparent waters. Juveniles of A. lyolepis were captured basically in the outermost site in the bay (site 1), where the influence of the sea is the highest. Anchoa tricolor and A. lyolepis may have different strategies as they coexist in the outer zone. There is also a conspicuous morphological difference between these two species, with the former showing a fairly short and blunt snout, while the latter, a prominent and pointed snout. Differences in morphological features between species have been used as indices of differences in resource use (Strong, 1984). Coexistence of morphologically or physiologically different phenotypes, as well as the behavioral or microgeographic diversity mentioned above, would be useful on both individual and population levels for exploitation of a diversified niche, and it is therefore probable that under the above conditions the population would be more variable than if it occupied a narrower niche (Van Valen, 1965). Furthermore, some arguments have been raised against this hypothesis because there are important interspecific habitat differences in sibling species which do not differ morphologically (Storch \& Frynta, 2000).

Juveniles of $A$. januaria recruit mostly in the inner bay zone, which suffer more influence of continental drainage and effluent discharges from urban-industrial areas. Anchoa januaria showed indications of preference for estuarine areas such as lower rivers reaches (Araújo et al., 2002). Sergipense \& Sazima (1995) also found A. januaria in higher abundance in sites in the inner zone between 1983 and 1985. Santos et al. (2007) reported that $A$. januaria in Sepetiba Bay shows movements between feeding areas (sandy beaches in the inner Bay) and spawning areas (lower rivers reaches), another evidence that this species use low salinity waters in the bay.

Juveniles of Cetengraulis edentulus rarely occurred in the beach seines, suggesting a different recruitment area other than the shallow sandy beaches of the Sepetiba Bay. Its recruitment probably takes place in deeper bay zones, where the sediment is mainly muddy, or outside the bay. Gay et al. (2000) reported that the distribution of this species in Itaipu lagoon, a coastal lagoon in the Rio de Janeiro State, is associated to muddy substrate.

Engraulis anchoita did not spend early life period in the Sepetiba Bay, since no young-of-the-year was recorded in the
Table 6. Summary of the CCA performed on the abundance of adults species of Engraulidae family. Significant environmental variables were selected by a stepwise procedure analogous to forward elimination in multiple regression analysis. Significant values $(\mathrm{p}<0.05)$ in bold.

\begin{tabular}{|c|c|c|c|c|}
\hline AXES & 1 & 2 & 3 & 4 \\
\hline \multicolumn{5}{|c|}{ Correlation of environmental variables } \\
\hline Salinity & -0.6003 & 0.5273 & -0.0022 & 0.0000 \\
\hline Temperature & -0.4254 & -0.6106 & 0.0346 & 0.0000 \\
\hline Transparency & -0.4651 & 0.1470 & -0.0591 & 0.0000 \\
\hline \multicolumn{5}{|c|}{ Summary statistics for ordination axes } \\
\hline Eigenvalues & 0.633 & 0.204 & 0.010 & 0.621 \\
\hline Species-environment correlations & 0.869 & 0.732 & 0.144 & 0.000 \\
\hline \multicolumn{5}{|c|}{ Cumulative percentage of variance } \\
\hline of species data & 37.0 & 48.9 & 49.5 & 85.7 \\
\hline of species-environment correlations & 74.8 & 98.8 & 100.0 & 0.0 \\
\hline Sum of al unconstrained eigenvalues & \multicolumn{4}{|c|}{1.713} \\
\hline Sum of all canonical eigenvalues & \multicolumn{4}{|c|}{0.847} \\
\hline
\end{tabular}

beaches. Only a few juveniles were occasionally captured in a sand beach outside the bay. It is understood that this species distribution area is farther south, ranging from Latitude $23^{\circ}$ to $33^{\circ} \mathrm{S}$ in open areas on the continental shelf, where it is target of large fisheries (Nakatani, 1982). Figueiredo \& Menezes (1978) reported that E. anchoita is the only species of Engraulidae family to be found in deeper coastal waters in the continental shelf.

Adaptative strategies developed by species, mainly linked to spawning periods, allow the larvae and juveniles to increase survival rate in most favorable food availability, allowing fast growth and more efficient predator avoidance. In the Sepetiba Bay there is no available information on this seasonality, but some example in other areas could be mentioned. According to Macgregor \& Houde (1996) seasonal abundance of eggs and larvae of $A$. mitchilli in Chesapeake are linked to seasonal food availability trigged by nutrient from seasonal rainfall.

Adults of A. tricolor penetrate into Sepetiba Bay mainly during late Winter, staying in the area until late Summer. Anchoa lyolepis, A. januaria and C. edentulus showed highest abundance in Spring. Spring is also considered as the season which favors high abundance of anchovies in other similar environments (Rakocinski et al., 1992; Sans et al., 1992; Paiva-Filho et al., 1986; Dorsey et al., 1996; Zastrow et al., 1991; Luo \& Musick, 1991). Engraulis anchoita adults, on the other hand, presented significant seasonal variations with the highest abundance in the Autumn, probably due to a very differentiated life cycle from the others Engraulidae. Few numbers of this species penetrate in the Sepetiba Bay during late Autumn and move away during late Winter. In late Spring this species forms "patches" in dense schoolings on the continental shelf (Sanchez, 1986).

Relationship between fish occurrence and environmental variables were assessed although statistical associations between fishes and measured environmental factors (salinity, temperature, etc.) do not necessarily prove cause and effect. Juveniles of $A$. tricolor were related to lowest temperatures, which coincide with the spawning peaks during late Winter/ early Spring (Silva et al., 2004). In Spring 1999/2000 tem- 
peratures were relatively higher and juvenile occurrences were lowest when compared to the previous year, and this could be an indication of suitability of lowest temperature for the recruitment success. Adults did not follow the same occurrence pattern in relation to temperature, since their highest captures occur in higher temperatures in the Summer. Anchoa januaria showed a wider occurrence in the ranges of examined temperature. Cetengraulis edentulus presented higher abundance in the highest temperatures, and this is also due to its highest occurrence in the inner zone. Salinity was probably the main environmental parameter to contribute for spatial separation of the most abundant Engraulidae species in the Sepetiba Bay. Juveniles and adults of $A$. tricolor were more abundant in higher salinity, while A. januaria and $C$. edentulus in lower salinity; these two latter species occur mainly in the area that receives the highest contribution of continental drainage. May \& MacArthur (1972) reported that the relationship between environmental variability and niche overlap implies that several species compete on a onedimensional continuum of resources. The location of the peak gives the optimal environment for that phenotype, the height of the peak is the measure of the best performance in the optimal environment, and the breadth of the curve is a measure of the tolerance for non-optimal environments (Levins, 1968). Each species is distributed according to its own genetic, physiological, and population characteristics and its own way of relating to environmental factors; hence no two species are distributed alike. Species respond in differing ways to factors that vary within communities in space and time, and such differences determine which species can coexist (Whittaker \& Levin, 1975). This principle of competitive exclusion is not the only response for coexistence mechanisms. Patterns of species occupancy of habitats depend on the densities of the interacting species, the competitive hierarchy among them, the presence of detectable intra-type variation in patch quality, and on their fundamental habitat preferences (Rosenzweig, 1981, 1991). Allen et al. (1995) found that the entrance of Anchoa mitchilli (Valenciennes, 1848), during the Spring in estuaries of Carolina of the South (USA), causes a redistribution of other planktivorous species, with predominant $A$. mitchilli occurring in the deep part of the water column, while Anchoa hepsetus (Linnaeus, 1758) and Menidia menidia (Linnaeus, 1766) that were distributed in whole water column, concentrate in the upper parts near to the surface.

Overall, spatial partition is the main mechanism developed by the most abundant Engraulidae species to coexist in the Sepetiba Bay, with $A$. tricolor using the outer zone, while $A$. januaria, the inner zone. This two abundant species probably evolved in a differentiate way to adapt at different environmental conditions, avoiding competition. The assumption that former competition is the general cause of species differences in communities has been satirically termed "the ghost of competition past" (Connell, 1980). This also could be an acceptable hypothesis for the coexistence in high abundance of this closed related group of fishes in the Sepetiba Bay. Significant interespecif differences in habitat selection requirements are strongly species-specific, with some overlap in the distribution among the species probably due to the preferred features of habitat are not exclusive.

\section{Acknowledgements}

We thank André Luiz Machado Pessanha and Pablo Mendonça for helping with field work; and the technical staff of the Laboratory of Fish Ecology, University Federal Rural of Rio de Janeiro, for generous assistance. This paper was benefited with the comments and criticism of Dr. João Paes Vieira. This article is a portion of MSc Dissertation of the second author, and received financial support from $\mathrm{CNPq}$ - Conselho nacional de Desenvolvimento Científico e Tecnológico.

\section{Literature Cited}

Allen, D. M., W. S. Johnson \& V. O. Matthews. 1995. Trophic relationships and seasonal utilization of salt-marsh creeks by zooplanktivorous fishes. Environmental Biology of Fishes, 42: 37-50.

Araújo, F. G., M. C. C. Azevedo, M. A. Silva, A. L. M. Pessanha, I. D. Gomes \& A. G. Cruz-Filho. 2002. Environmental influences on the demersal fish assemblages in the Sepetiba Bay, Brazil. Estuaries, 25: 441-450.

Barbieri, E. B. \& D. M. P. Kronemberger. 1994. Climatologia do Litoral Sul-Sudeste do Estado do Rio de Janeiro. Cadernos de Geociências, 12: 57-73.

Connell, J. H. 1980. Diversity and the coevolution of competitors, or the ghost of competition past. Oikos, 35: 131-138.

Coto, C. F., A. O. Luna, A. L. Calvo \& F. Z. García. 1988. Abundancia de algunas especies de Anchoas en la laguna de Términos (México), estimada atraves de la captura de huevos. Annal del Institute de Ciências del Mar y Limnologia da Universidad Autónoma de México, 15: 125-134.

Dorsey, S. E., E. D. Houde \& J. C. Gamble. 1996. Cohort abundances and daily variability in mortality of eggs and yolk-sac larvae of bay anchovy, Anchoa mitchilli, in Chesapeake Bay. Fishery Bulletin, 94: 257-267.

Figueiredo, J. L. \& N. A. Menezes. 1978. Manual de peixes marinhos do sudeste do Brasil. II. Teleostei (I). Museu de zoologia da USP, São Paulo, 110p.

Gay, D., S. Sergipense \& C. F. D. Rocha. 2000. Ocorrência e distribuição de Cetengraulis edentulus (Curvier, 1829) (Teleostei, Engraulidae) na Laguna de Itaipu, Niterói, Rio de Janeiro, Brasil. Revista Brasileira de Zoologia, 17: 463-472.

Hildebrand, S. F. 1963. Family Engraulidae. Memoiries Sears Foundation for Marine Research, 1: 152-249.

Levins, R. 1968. Evolution in Changing environments: Some theoretical explorations. Princeton University Press., Princeton, U.S.A., 132p.

Lowe-McConnell, R. H. 1987. Ecological studies in tropical fish communities. Cambridge University Press, Cambridge, 382p.

Luo, J. \& J. Musick. 1991. Reproductive biology of the bay anchovy in Chesapeake Bay. Transaction of the American Fisheries Society, 120: 701-710.

Macgregor, J. M. \& E. D. Houde. 1996. Onshore-Offshore pattern and variability in distribution and abundance of bay anchovy Anchoa mitchilli eggs and larvae in Cheasapeake Bay. Marine Ecology Progress Series, 138: 15-25. 
May, R. M. \& R. H. MacArthur. 1972. Niche overlap as a function of environmental variability. Proceedings of the Natural Academy of Sciences USA, 69: 1109-1113.

Mcgowan, M. F. \& F. H. Berry. 1983. Clupeiformes: Development and Relationships. pp. 108-126. In. Blaxter, J.H.S. (Ed.), Ontogeny and Systematics of Fishes - Ahlstrom Symposium. American Society of Ichthyologists and Herpetologists, California, 8.

Nakatani, K. 1982. Estudos sobre os ovos e larvas de Engraulis anchoita (Hubbs \& Marinii, 1935) (Teleostei, Engraulidae) coletados na região entre Cabo Frio $\left(23^{\circ}\right)$ e Cabo de Santa Marta $\left(29^{\circ}\right)$. Unpublished M.Sc. Dissertation, Universidade de São Paulo, São Paulo, 167p.

Paiva-Filho, A. M., M. L. T. Zani \& P. K. Kihara. 1986. Contribuição ao conhecimento da Biologia da manjuba, Anchoviella lepidentostole (Fowler, 1911), no estuário de São Vicente, SP (Osteichthyes, Engraulidae). Boletim do Instituto Oceanográfico, 34: 71-77.

Pessanha, A. L. M., F. G. Araújo, M. C. C. Azevedo \& I. D. Gomes. 2003. Diel and seasonal changes in the distribution of fish on a southeast Brazil sandy beach. Marine Biology, 143: 1047-1055.

Rakocinski, C. F., D. M. Baltz \& J. W. Fleeger. 1992. Correspondence between environmental gradients and the community structure of marsh-edge fishes in a Louisiana estuary. Marine Ecology Progress Series, 80: 135-148.

Ricklefs, R. E. \& D. Schluter. 1993. Species diversity in ecological communities. Historical and Geographical Perspectives. The University of Chicago Press, Chicago UP, 454p.

Rodríguez, M. A. \& W. M. Lewis. 1997. Structure of fish assemblages along environmental gradients in floodplain lakes of the Orinoco River. Ecological Monographs 67: 109-128.

Rosenzweig, M. L.1981. A theory of habitat selection. Ecology, 62: 327-335.

Rosenzweig, M. L. 1991. Habitat selection and populations interactions: the search for mechanism. American Naturalist, 137: S5-S28.

Rountree, R. A. \& K. W. Able. 1997. Nocturnal fish use of a New Jersey marsh creek and adjacent bay shoal habitats. Estuarine, Coastal and Shelf Science, 44: 703-711.

Sanchez, R. P. 1986. Estudio sobre las variaciones espacio-temporales en los patrones de distribución de embriones de Engraulis anchoita, en relación con la estimación de su intensidad reproductiva. Revista de Investigación y Desarrollo Pesquero, 5: 92-142.

Sans, A., L. Motos \& A. Uriarte. 1992. Daily fecundity of the Bay of Biscay anchovy, Engraulis encrasicolus (L.), population in 1987. Boletin del Instituto Español de Oceanografia, 8: 203-213.

Santos, J. N. S., F. G. Araújo, M. A. Silva \& R. M. Vasconcellos. 2007. Sex ratio and sexual dimorphism of the anchovy Anchoa januaria (Actinopterygii, Engraulidae) in a tropical bay in southeastern Brazil. Journal of Fish Biology, 71: 877-888.
Sergipense, S., E. P. Caramaschi \& I. Sazima. 1999. Morfologia e hábitos alimentares de duas espécies de Engraulidae (Teleostei, Clupeiformes) na Baía de Sepetiba, Rio de Janeiro. Revista Brasileira de Oceanografia, 47: 173-188.

Sergipense, S. \& I. Sazima. 1995. Variações sazonais de ocorrência e tamanho em duas espécies de Engraulidae (Osteichthyes) na Baía de Sepetiba, Rio de Janeiro. Revista Brasileira de Biologia, 55: 491-501.

Silva, M. A. \& F. G. Araújo. 2000. Distribution and relative abundance of anchovies (Clupeiformes-Engraulididae) in the Sepetiba Bay, RJ. Brazil. Brazilian Archives of Biology and Technology, 43: 379-385.

Silva, M. A., F. G. Araújo, M. C. C. Azevedo \& J. N. S. Santos. 2004. The nursery function of sandy beaches in a Brazilian tropical bay for 0-group anchovies (Teleostei: Engraulidae): diel, seasonal and spatial patterns. Journal of Marine Biological Association U.K., 84: 1229-1232.

Sokal, R. R. \& F. J. Rohlf. 1981. Biometry: The principles and practice of statistic in biological research New York. Freeman \& Company, 859p.

Storch, D. \& D. Frynta. 2000. Evolution of habitat selection: Stochastic acquisition of cognitive clues? Evolutionary Ecology, 13: 591-600.

Strong, D. R. 1984. Exorcising the ghost of competition past: Phytophagus insects. Pp. 28-41. In: Strong, D. R., Simberloff, Abele, D. L. G. \& A. B.Thistle. (Eds.). Ecological communities: conceptual issues and the evidence. Princeton University Press, Princeton, New Jersey, pp. 28-41.

Ter Braak, C. J. F. 1986. Canonical correspondence analysis: a new eigenvector techinique for multivariate direct gradient analysis. Ecology, 67: 1167-1179.

Van Valen, L. 1965. Morphological variation and width of ecological niche. American Naturalist, 99: 377-390.

Weiss, G. \& L. C. Krug. 1977. Características do desenvolvimento e metamorfose de Lycengraulis olidus (Engraulidae) e Brevortia Pectinata (Clupeidae) no estuário da Lagoa dos Patos, desova invernal de Engraulis anchoita na costa sul do Brasil em 1970 e 1976. Atlântica, 2: 83-117.

Whittaker, R. H. \& S. A. Levin. 1975. Niche: Theory and Application. Benchmark Papers in Ecology/3. Dowden, Hutchinson \& Ross, Inc., Stroudsburg, PA. 448p.

Zastrow, C. E., E. D. Houde \& L. G. Morin. 1991. Spawning, fecundity, hatch-date frequency and young-of-the-year growth of bay anchovy Anchoa mitchilli in mid Chesapeake Bay. Marine Ecology Progress Series, 73: 161-171.

Accepted August 2008 Published December 22, 2008 